\title{
Research on the Impact of Information Security Certification and Concealment on Financial Performance:
} Impact of ISO 27001 and Concealment on Performance

\author{
Wenqing Wu, College of Management and Economics, Tianjin University, Tianjin, China \\ Kun Shi, College of Management and Economics, Tianjin University, Tianjin, China \\ Chia-Huei Wu, Institute of Service Industries and Management, Minghsin University of Science Technology, Xinfeng, \\ Taiwan \\ iD https://orcid.org/0000-0001-6399-2113
}

Jiayue Liu, School of Marine Science and Technology, Tianjin University, Tianjin, China

\begin{abstract}
With the rapid development of information technology, information security has been gaining attention. The International Organization for Standardization (ISO) has issued international standards and technical reports related to information security, which are gradually being adopted by enterprises. This study analyzes the relationship between information security certification (ISO 27001) and corporate financial performance using data from Chinese publicly listed companies. The study focusses on the impact of corporate decisions such as whether to obtain certification, how long to hold certification, and whether to publicize information regarding certification. The results show that there is a positive correlation between ISO 27001 and financial performance. Moreover, the positive impact of ISO 27001 on financial performance gradually increases with time. In addition, choosing not to publicize ISO 27001 certification can negatively affect enterprise performance.
\end{abstract}

\section{KEYWORDS}

Certification Experience, Certification Publicity, Enterprise Performance, Financial Performance, Information Security Certification, Information Security Threat, International Standards, ISO 27001

\section{INTRODUCTION}

The rapid development and wide application of information technology can facilitate companies' information management; however, it also creates security challenges (Yaokumah, et al., 2019). Improper use of information technology can cause the unintended disclosure of personal or company documentation which can damage the corporate image and reduce business volume (Bidgoli, 2006); therefore, information security protection has become increasingly important. Information security management system certification ISO 27001 was issued in response to the business need for information technology and security management. ISO 27001 standard originated from the British 
Standards Institution's BS 7799 and was officially issued by the International Standards Organization (ISO) in 2005. ISO 27001 standard has gained wide attention since its introduction; by 2018 , ISO had established 59,934 ISO 27001 sites in 125 countries and regions and issued 31,910 valid certificates (ISO, 2018).

ISO 27001 certification provides a scientific standard for defending against information security breaches and assessing organizational information security. It synthesizes, arranges, and provides a set of detailed rules using best practice (ISO, 2013). In practice, ISO 27001 standard is considered to be an accurate and effective information security management tool. The standard also coordinates information management of electronic transactions from multiple perspectives to help firms gain business transaction credits, and its adoption into an enterprise's management system is expected to result in improved financial performance.

Some scholars have discussed the value of implementing information security management systems in enterprises. Hall (2011) discusses the relationship between information security and organizational capacity and suggests that having an overall information security strategy can make enterprises better able to respond to the dynamic business environment and maintain brand strength and business flexibility. Okoye (2017) applies a multi-case study to understand how to minimize the impact of information security threats on small and medium-sized businesses. The results show that formulating an information security strategy can reduce the potential for damage to business performance caused by unintentional disclosure and misuse of information. Davis (2017) emphasizes the importance of information security in American corporate governance and its effectiveness in resolving the issue of declining customer trust caused by security breaches. Edwards (2011) notes that improving information security systems can help enterprises to prevent major consequences caused by information security breaches, including property loss, reduced business productivity, and efficiency decline. Spears (2007) provides evidence to suggest that the institutionalization of information security risk management can resolve inadequacies in information technology assets and improve operational performance. In sum, most existing research focuses on the effect of information security strategies in improving operational performance; however, there is currently no direct evidence of a relationship between ISO 27001 certification and financial performance. Therefore, it is necessary to determine the effect of information security certification on corporate financial performance. It is also important to understand the effect mechanisms of certification and the sustainability of these effects on corporate financial performance.

Certification requires a significant initial investment (Sharma, 2005) and challenges all levels of management and operation (Aba, et al., 2015). Studies have shown that implementing international standards rarely result in immediate performance improvement. For example, Song (2019) tests the economic benefits of adopting the environmental management certification ISO 14001 in Korean companies. The results conclude that an accumulation of implementation experience is required before gaining an improvement in performance. Similarly, Avdalovic, et al. (2018) suggest that enterprises need to take time to integrate the specific knowledge of the quality management certification ISO 9001 into business processes in order to realize sustainable improvement in performance. This study seeks to understand whether the continuous and consistent implementation of ISO 27001 system in the long- term will improve the level of information security, reduce unnecessary costs, gain the trust of customers, and improve performance.

ISO certification is closely related to an improvement in corporate reputation (Santos, et al., 2016); therefore, informing stakeholders of the attained certification can result in recognition from the board of directors and customers, and an improved financial performance in the next period (Lo, et al., 2011). However, scholars have found that some enterprises deliberately choose not to disclose existing measures or achievements such as ISO certification to avoid undesirable outcomes. For example, Froger, et al. (2015) find that some price-sensitive consumers tend to choose inexpensive products without eco-certification labels; therefore, some manufacturers do not advertise their ecocertification on their products. Edmondson (2011) identifies that some managers prefer to publish their 
inspection and improvement measures only after realizing positive effects, to help their organization recover from previous issues. According to Carlos and Lewis (2018), some organizations conceal rather than publish their certification in anticipation of unreasonable expectations, which reflects a lack of communication between managers and their key stakeholders. This study is expected to demonstrate the relationship between unpublished ISO 27001 certification and reduced financial performance.

To test our prediction, this paper takes Chinese listed companies as the research context. The Chinese government has placed a strong emphasis on information security certification. In 2008, China transformed ISO 27001 standard into national standard GB/T 22080:2008 and comprehensively promoted it to Chinese businesses. As early as March 2011, the Chinese government explicitly included ISO 27001 certification within the 12th Five Year Plan (M.C. Martí-Calatayud, 2011), resulting in high demand among Chinese enterprises for information security certification. According to 2019 data from the China Certification and Accreditation Administration (CNCA), 8,868 Chinese enterprises have obtained ISO 27001 certification.

This study selects 2,530 Chinese listed companies that obtained ISO 27001 certification between 2010 and 2017 and investigates the certification duration, publicity of information regarding the security management system certification, and financial performance. Comprehensive financial data was obtained through the China Stock Market and Accounting Research (CSMAR) database.

The main objective of this study is to determine whether adopting ISO 27001 certification increases financial performance. The next part of this paper is arranged as follows. The Background section introduces the hypothesis by analyzing the application of ISO 27001 standard in China. The Research Design is then outlined describing the experimental variables, data, and methods. Results are then provided along with a robustness check. Finally, to explore the relationship between ISO 27001 certification and enterprise performance, the Conclusion section provides suggestions for the implementation of an information security management system.

\section{Background}

Information security management is playing an increasingly important role for enterprises in creating a competitive advantage. Industrial production has come to rely on information technology, and information resources have become an important commercial asset (Lele \& Lihua, 2016). Various industries have steadily obtained the convenience of information technology for business optimization and integration (Hung, et al., 2019); however, attacks on enterprise information systems are becoming more frequent and diverse (Chang \& Seow, 2019). Latent issues in information security can become increasingly prominent, which can gradually affect the development of an enterprise (Moghe, et al., 2014). An ineffective enterprise information security management system cannot prevent information theft and can lead to property loss (Peltier, 2016); therefore, information security has gradually become a focus of attention (Dao, et al., 2017). Information security risk has unique characteristics in location, degree, and visibility, which cannot be fully solved by traditional insurance investment strategies (Gordon, 2003; Peng, et al., 2019). In this context, ISO 27001 standard provides an authoritative and effective institutional basis for the information security market and is, therefore, an important entry point in the information security management of enterprises.

The requirements of ISO 27001 standard contribute to an improvement in enterprise performance. On the one hand, the implementation of ISO 27001 system can build the trust of customers and increase business volume. According to the requirements of ISO 27001 standard, enterprises should ensure that their information security policy and strategic direction are consistent and that the information security system is integrated into the business process (ISO, 2013). These requirements include not only clarifying the organizational roles, responsibilities, and authorities of information security management personnel but also making reasonable plans for risk control measures and generating relevant adaptability statements. At the same time, these measures enable enterprises to curb computer virus attacks (Beckers, et al., 2014). These improvements promote customers' trust, reduce the cost of information security strategies, and promote a close relationship and cooperation 
between organizations (Al-Momani, et al., 2018; Nugraha \& Martin, 2017). On the other hand, the implementation of ISO 27001 system also helps companies to reduce unnecessary costs. The loss caused by information security issues can sometimes be transferred to consumers (Anderson, 2001); therefore, guaranteeing information security can provide a price advantage for a product or service (Wu \& Tsai, 2018). Similarly, ISO 27001 standard provides relevant measures to meet the requirements of efficiency in information communication and information record file retrieval. These measures reduce additional information management costs and create the possibility of improving profitability (Montiel, et al., 2012).

In an investigation of the effect of ISO 9001 certification on enterprise performance, Sampaio, et al. (2011) find that enterprises can achieve a higher profitability after passing the certification. Similarly, other studies have found that the implementation of ISO 14001 certification may improve a company's profitability by creating a positive financial market response (Lee, et al., 2017). Therefore, enterprises that adopt ISO 27001 certification can also expect to improve their profitability and financial performance, leading to the first hypothesis of this study:

Hypothesis One: There is a positive correlation between ISO 27001 certification and financial performance.

This study also examines the effect of accumulated certification experience on financial performance. According to the conditions of certification implementation, the ISO 27001 standard includes 14 fields and 113 security control measures to identify and manage information security risk elements (ISO, 2013). In the process of companies applying for ISO 27001 certification, a minimum of 11 aspects of comprehensive investigation and integration must be implemented (ISO, 2013). The early stages of implementing an international standard can seem complicated and requires a significant investment of time, capital, and human resources (Priede, 2012). A company must formulate a detailed system according to its own characteristics, and conduct multiple third-party audits to gradually improve the information security system (Ferreira Rebelo, et al., 2014). With an accumulation of experience, certified companies reduce costs, increase sales revenue, and increase asset turnover (Goedhuys \& Sleuwaegen, 2013; Sharma, 2005). In the early stages of the implementation of ISO 27001 system, it is possible that the financial performance will not be significantly improved; however, financial performance will continue to improve with experience.

An enterprise is unlikely to realize the financial benefits of ISO 27001 system in the early stages of implementation due to the substantial investment required. ISO 27001 system requires all employees, contractors, and third parties to be aware of information security threats, fulfill their information security responsibilities, and reduce human errors (ISO, 2013). To meet these requirements, personnel must be appointed to enhance information security awareness within the business, clarify tasks, and implement measures to ensure compliance (Abad, et al., 2013). A long-term cyclical training program is also required to ensure employees become familiar with certification requirements (Siponen, 2000). Employees need accumulated practical experience to reasonably adjust and improve the information security system to ensure it is consistently updated and maintained to the standard (Bulgurcu, et al., 2010; Tsai, et al., 2016). Moreover, Lafuente and Abad (2018) provide support for the accumulated experience of certification to improve a company's performance. Therefore, the second hypothesis of this study is:

Hypothesis Two: Accumulated ISO 27001 system experience has a positive impact on financial performance.

Obtaining an ISO certification can indicate that an enterprise has high credibility, which can attract more customers (Terlaak \& King, 2006). However, customers may find it difficult to perceive 
changes without being advised of the newly acquired certification, and therefore may not respond positively (Cheng, et al., 2019). It is expected that the high investment in certification will be rewarded with higher profitability, otherwise, certification may cause a decline in overall financial performance (Goedhuys \& Sleuwaegen, 2013; Priede, 2012). Some enterprises do not publish their ISO 27001 certification, particularly in the early stages of implementation, which may have a negative impact on financial performance.

In anticipation of unfavorable effects, a manager may choose not to publish their certification results (Carlos \& Lewis, 2018). For example, an enterprise may already have a good reputation and managers may worry that if the relevant certification is published, stakeholder expectations will increase (Elving, et al., 2015). If the enterprise then fails to achieve the relevant performance objectives after obtaining the certification, stakeholders may suspect that the manager has not successfully implemented the new system (Gallivan, 2001), leading to an investigation (Lyon \& Montgomery, 2013). To avoid investigations, passive managers choose to keep the certification strategy silent (Carlos \& Lewis, 2018). However, the implementation of ISO 27001 system needs the full cooperation of personnel, and failure to reveal certification results is not conducive to the overall implementation of the information security strategic plan (ISO, 2013). If the information security issues cannot be identified, the risk of property loss caused by information security breaches still exists. Therefore, failing to disclose ISO 27001 certification may hinder the improvement of financial performance.

For enterprises that have been impacted in the past by information security issues, the release of relevant certification information may be perceived by stakeholders as a way to divert their attention from past performance issues (Godfrey, 2005). Stakeholders tend to increasingly distrust managers and suspect that managers are essentially inactive (Carlos \& Lewis, 2018). Passive managers may hide their efforts to address performance issues, including concealing certification. However, the media and consumers have a negative attitude towards concealment, even if it is intended in good faith (Lin, et al., 2015). If consumers perceive such concealment, they will respond by reducing their business dealings with these enterprises, leading to the third hypothesis of this study:

Hypothesis Three: Unpublished ISO 27001 certification has a negative effect on financial performance.

\section{Research design}

\section{Variables}

\section{Dependent Variable}

In certification literature, many scholars choose Return on Assets (ROA) to measure financial performance. For example, Lo, et al. (2012) tests the impact of ISO 14001 certification on ROA in the fashion and textile manufacturing industry, including the role in the initial stage of certification implementation and the role of continuous certification. Siougle, et al. (2018) use ROA to measure financial performance in the research of ISO 9000 certification. Lafuente and Abad (2018) tests how the implementation of occupational health and safety certification OHSAS 18001 affected corporate performance and used ROA to measure financial aspects. This study, therefore, also uses ROA as the standard to measure financial performance.

\section{Independent Variable}

In this study, ISO 27001 certification data of listed companies from 2010 to 2017 were collated from the official website of the CNCA. Two virtual variables were established: whether to certify (ISO 27001), and whether to publicly certify (Unpublic). The variable ISO 27001 indicates whether the company is certified in the current year. If yes, the variable equals 1 , otherwise, it equals 0 . The variable Unpublic indicates whether ISO 27001 certification has been obtained but not disclosed. 
Table 1. Definition and measurement of variables

\begin{tabular}{|l|l|l|}
\hline Type & Variable name & Definition \\
\hline $\begin{array}{l}\text { Dependent } \\
\text { variable }\end{array}$ & ROA & The ratio of net profit to average balance of total assets. \\
\hline $\begin{array}{l}\text { Independent } \\
\text { variables }\end{array}$ & ISO 27001 & $\begin{array}{l}\text { If the firm certifies ISO 27001 certification, it equals 1; otherwise, it } \\
\text { equals 0. }\end{array}$ \\
\cline { 2 - 3 } & Unpublic & $\begin{array}{l}\text { If the firm publishes ISO 27001 certification, it equals to 1; if not, it equals } \\
\text { 0. }\end{array}$ \\
\cline { 2 - 3 } & Experience & $\begin{array}{l}\text { Experience is measured as the difference between the observation year and } \\
\text { the first certified year. }\end{array}$ \\
\hline \multirow{5}{*}{ Control variables } & Size & Natural logarithm of total assets at the end of that year. \\
\cline { 2 - 3 } & Asset Liability Ratio & Ratio of total liabilities to total assets. \\
\cline { 2 - 3 } & Current Ratio & Ratio of current assets to current liabilities. \\
\cline { 2 - 3 } & Operating Cost Rate & $\begin{array}{l}\text { The proportion of various expenses that the enterprise spends on business } \\
\text { activities in the operating income in the year. }\end{array}$ \\
\cline { 2 - 3 } & $\begin{array}{l}\text { Retained Earnings } \\
\text { Rate }\end{array}$ & $\begin{array}{l}\text { Retained earnings is the difference of the company's after-tax profit from } \\
\text { the cash dividends payable. Retained earnings rate is the ratio of retained } \\
\text { earnings to after-tax profit. }\end{array}$ \\
\cline { 2 - 3 } & $\begin{array}{l}\text { Growth Rate } \\
\text { Subtract the previous year's operating income from the current year's } \\
\text { operating income to get a difference. Ratio of this difference to the } \\
\text { previous year's operating income is defined as growth. }\end{array}$ \\
\cline { 2 - 3 } & SOE & \begin{tabular}{l} 
SOE equals 1 when the enterprise is state-owned, otherwise it equals 0. \\
\hline
\end{tabular}
\end{tabular}

If yes, Unpublic equals 1 , otherwise, it equals 0 . In addition, experience of information security management system certification is considered as an independent variable, expressed as the difference between the current year and the first certification year.

\section{Control Variables}

This study controls five key elements for each enterprise: company size; debt structure, measured by asset-liability ratio and current ratio; operating level, measured by the operating cost rate and retained earnings rate; growth rate; and ownership status, indicated as either state-owned (SOE) or otherwise. These variables are defined in Table 1 . The industry and the year are also controlled for all models. All variables used for this study are presented in Table 1.

\section{Data}

Certification data for 2,530 Chinese listed companies were obtained from CNCA, followed by financial data from the CSMAR database. The listed companies with incomplete certification data, discontinuous certification time or outside the observation period were excluded, and the data were processed by a $1 \%$ reduction. Finally, the data of 1,904 listed companies were obtained, with a total of 10,627 observations. Descriptive statistical results are shown in Table 2 and the correlation matrix is shown in Table 3.

It can be seen from Table 2 that only $4.0 \%$ of the samples that obtained ISO 27001 certification and disclosed this information to the public, the certified rate of ISO 27001 certification still has a large growth space. The maximum time of certification is 14 years demonstrating that some enterprises were early adopters of ISO 27001 certification. Some enterprises may not realize the effectiveness of the measures proposed by ISO 27001 standard, or think that the investment cost of certification is too high. The average Unpublic value is 0.006 , which means that $0.6 \%$ of the samples did not 
Table 2. Descriptive Statistics

\begin{tabular}{|c|c|c|c|c|c|}
\hline Variable & Obs. & Mean & Std. Dev. & Min & Max \\
\hline ROA & 10627 & 0.051 & 0.039 & 0.000 & 0.188 \\
\hline ISO 27001 & 10627 & 0.040 & 0.196 & 0 & 1 \\
\hline Experience & 10627 & 0.105 & 0.694 & 0 & 14 \\
\hline Unpublic & 10627 & 0.006 & 0.076 & 0 & 1 \\
\hline Size & 10627 & 21.888 & 1.180 & 19.846 & 25.700 \\
\hline Asset Liability Ratio & 10627 & 0.388 & 0.197 & 0.049 & 0.936 \\
\hline Current Ratio & 10627 & 2.828 & 2.958 & 0.296 & 18.053 \\
\hline Operating Cost Rate & 10627 & 0.715 & 0.156 & 0.217 & 1.012 \\
\hline Retained Earnings Rate & 10627 & 0.690 & 0.323 & -1.026 & 1.000 \\
\hline Growth Rate & 10627 & 0.291 & 0.586 & -0.632 & 3.395 \\
\hline SOE & 10627 & 0.139 & 0.346 & 0 & 1 \\
\hline
\end{tabular}

Table 3. Correlation Matrix

\begin{tabular}{|c|c|c|c|c|c|c|c|c|c|c|c|}
\hline & 1 & 2 & 3 & 4 & 5 & 6 & 7 & 8 & 9 & 10 & 11 \\
\hline ROA & 1 & & & & & & & & & & \\
\hline ISO 27001 & $0.041 * * *$ & 1 & & & & & & & & & \\
\hline Experience & $0.045^{* * *}$ & $0.645^{* * * *}$ & 1 & & & & & & & & \\
\hline Unpublic & $0.028 * * *$ & -0.016 & $0.245^{* * * *}$ & 1 & & & & & & & \\
\hline Size & $-0.100^{* * * *}$ & $0.027 * * *$ & $0.051^{* * *}$ & 0.007 & 1 & & & & & & \\
\hline $\begin{array}{l}\text { Asset Liability } \\
\text { Ratio }\end{array}$ & $-0.397 * * *$ & $-0.021 * *$ & -0.013 & $-0.017^{*}$ & $0.534 * * *$ & 1 & & & & & \\
\hline Current Ratio & $0.265^{* * *}$ & -0.002 & 0.008 & $0.017 *$ & $-0.387 * * *$ & $-0.675 * * *$ & 1 & & & & \\
\hline $\begin{array}{l}\text { Operating } \\
\text { Cost Rate }\end{array}$ & $-0.496^{* * * *}$ & $-0.089^{* * * *}$ & $-0.082^{* * * *}$ & $-0.053 * * *$ & $0.238 * * *$ & $0.471 * * *$ & $-0.412 * * *$ & 1 & & & \\
\hline $\begin{array}{l}\text { Retained } \\
\text { Earnings Rate }\end{array}$ & -0.005 & 0.016 & $0.018^{*}$ & -0.005 & $0.027 * * *$ & $0.187 * * *$ & $-0.157 * * *$ & $0.047 * * *$ & 1 & & \\
\hline Growth Rate & $-0.020 * *$ & $0.154 * * *$ & $0.120 * * *$ & $0.038 * * *$ & $-0.076 * * *$ & $-0.024 * *$ & $0.026^{* * *}$ & $-0.150 * * *$ & 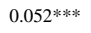 & 1 & \\
\hline SOE & $-0.094 * * *$ & $0.018 *$ & $0.028 * * *$ & $0.019^{* *}$ & $0.207 * * *$ & $0.202 * * *$ & $-0.124 * * *$ & $0.169 * * *$ & $0.063^{* * * *}$ & $0.050^{* * * *}$ & 1 \\
\hline
\end{tabular}

disclose their certifications in time. For all certified samples, the proportion of unpublished certified samples is up to $13.04 \%$.

\section{Methods}

In order to control the influence of confounding factors, some scholars have used matched samples to study certification's impact on enterprise performance (Siougle, et al., 2018). Considering the possibility of selective bias in obtaining ISO 27001 certification, this study used the Coarsened Exact Matching (CEM) method to match the covariates between the variable group (obtaining ISO 27001 certification) and the control group (never obtained ISO 27001 certification) to enhance the comparability between the sample data (Iacus, et al., 2009, 2011). Considering the large demand 
difference between different industries in the information security market, the industry and the year were chosen as the matching covariates. In addition, some scholars believe that the implementation effect of certification is closely related to enterprise ownership (Ullah, et al., 2014), therefore $S O E$ is regarded as a matching covariate. After matching, the sample balance index decreased from 0.690 to 0.168 , indicating that the matching effect was appropriate. Finally, 7,618 matched observations were obtained from 1,789 companies.

The following model was used to test the three hypotheses:

$$
\begin{aligned}
& R_{i t}=\beta_{0}+\beta_{1}{\text { ISO } 27001_{i t}+\beta_{2} \text { Controls }_{i t}+\varepsilon_{i t}} \\
& \text { ROA }_{i t}=\beta_{0}+\beta_{1} \text { Experience }_{i t}+\beta_{2} \text { Controls }_{i t}+\varepsilon_{i t} \\
& \text { ROA }_{i t}=\beta_{0}+\beta_{1} \text { Unpublic }_{i t}+\beta_{2} \text { Controls }_{i t}+\varepsilon_{i t}
\end{aligned}
$$

Equation (1) explains Hypothesis One; Equation (2) and Equation (3) test Hypothesis Two and Hypothesis Three respectively; is the dependent variable; are independent variables; refers to the vector of a series of control variables of company $i$ in year $t$; and indicates the error item. If Hypothesis One is established, that is, the financial performance of the variable group exceeds that of the control group, of Equation (1) should be positive and significant. of Equation (2) explains the relationship between the duration of certification and performance, and of Equation (3) reflects the difference between published and unpublished certification.

\section{Empirical Results}

The first goal of this study is to reflect the relationship between information security certification and financial performance. The results of the data regression are shown in Model 1 in Table 4. The coefficient of ISO 27001 (of Equation (1)) reflects the difference in financial performance between the certified enterprise and the enterprise that has never certified ISO 27001. was calculated as 0.008, which was significant at the $1 \%$ level. As a result, the financial performance of enterprises obtaining information certification has increased significantly, which is consistent with Hypothesis One.

Hypothesis Two suggests that with the accumulation of ISO 27001 experience, management practices are optimized and financial performance is gradually improved. The results of Model 2 in Table 4 show the Experience coefficient is significant at the 5\% level. This result supports Hypothesis Two; familiarity with the implementation of certification, training of personnel, publicity, and acceptance of the significance of certification all lead to an improvement in the reliability and efficiency of information security and therefore improve profitability.

The results relating to Hypothesis Three are reported in Model 3 of Table 4. The hypothesis states that the implementation of information security certification should be publicized, even in the early stages of certification when the expected benefits of certification are uncertain. The results show that the Unpublic coefficient is - 0.014 , and the significance level is lower than $1 \%$. Therefore, certification without publicity does harm financial performance, and Hypothesis Three is therefore verified. As expected, the recognition established by customers and contractors based on certification is the main reason for the improvement of financial performance. The contribution of implementing ISO 27001 system to attracting customers may be even greater than its contribution to information security management. 
Table 4. Regression Results

\begin{tabular}{|c|c|c|c|c|c|c|}
\hline \multirow{2}{*}{ VARIABLES } & \multicolumn{2}{|l|}{ Model 1} & \multicolumn{2}{|l|}{ Model 2} & \multicolumn{2}{|l|}{ Model 3} \\
\hline & Coefficient & $V I F$ & Coefficient & $V I F$ & Coefficient & $V I F$ \\
\hline \multirow[t]{2}{*}{ IS O $\quad 27001$} & $0.008 * * *$ & 1.048 & & & & \\
\hline & $(0.002)$ & & & & & \\
\hline \multirow[t]{2}{*}{ Experience } & & & $0.003 * *$ & 1.044 & & \\
\hline & & & $(0.000)$ & & & \\
\hline \multirow[t]{2}{*}{ Unpublic } & & & & & $-0.014 * * *$ & 1.057 \\
\hline & & & & & $(0.002)$ & \\
\hline \multirow[t]{2}{*}{$\mathrm{S}$ i z e } & $0.002 * * *$ & 1.600 & $0.002 * * *$ & 1.601 & $0.002 * * *$ & 1.587 \\
\hline & $(0.000)$ & & $(0.000)$ & & $(0.000)$ & \\
\hline \multirow[t]{2}{*}{ Asset Liability Ratio } & $-0.041 * * *$ & 2.336 & $-0.041^{* * *}$ & 2.336 & $-0.041^{* * *}$ & 2.336 \\
\hline & $(0.003)$ & & $(0.003)$ & & $(0.003)$ & \\
\hline \multirow[t]{2}{*}{ Current Ratio } & 0.000 & 1.922 & 0.000 & 1.923 & 0.000 & 1.922 \\
\hline & $(0.000)$ & & $(0.000)$ & & $(0.000)$ & \\
\hline \multirow[t]{2}{*}{ Operating Cost Rate } & $-0.078 * * *$ & 1.758 & $-0.077 * * *$ & 1.757 & $-0.078^{* * *}$ & 1.760 \\
\hline & $(0.003)$ & & $(0.003)$ & & $(0.003)$ & \\
\hline \multirow[t]{2}{*}{ Retained Earnings Rate } & $0.015 * * *$ & 1.074 & $0.015^{* * *}$ & 1.074 & $0.015 * * *$ & 1.074 \\
\hline & $(0.001)$ & & $(0.001)$ & & $(0.001)$ & \\
\hline \multirow[t]{2}{*}{ Growth Rate } & $-0.001 *$ & 1.192 & $-0.001 *$ & 1.191 & $-0.001 *$ & 1.190 \\
\hline & $(0.001)$ & & $(0.001)$ & & $(0.001)$ & \\
\hline \multirow[t]{2}{*}{ SO E } & $-0.006 * * *$ & 1.265 & $-0.006 * * *$ & 1.263 & $-0.006^{* * *}$ & 1.271 \\
\hline & $(0.001)$ & & $(0.001)$ & & $(0.001)$ & \\
\hline Year Control & Yes & & Yes & & Yes & \\
\hline Industry Control & Yes & & Yes & & Yes & \\
\hline \multirow[t]{2}{*}{ Constant } & $0.111 * * *$ & & $0.109^{* * *}$ & & $0.105 * * *$ & \\
\hline & $(0.017)$ & & $(0.017)$ & & $(0.017)$ & \\
\hline Observations & 7,618 & & 7,618 & & 7,618 & \\
\hline $\mathrm{R}$ - squared & 0.263 & & 0.261 & & 0.265 & \\
\hline $\mathrm{F}$ test & 57.58 & & 56.95 & & 58.01 & \\
\hline
\end{tabular}

${ }^{* * *} p<0.01,{ }^{* *} p<0.05,{ }^{*} p<0.1$

\section{Robustness Check}

To further test the reliability of the results, a robustness analysis was undertaken. Some scholars have proposed return on equity (ROE) as a standard to test financial performance. For example, Nga (2009) uses samples from 81 companies in Malaysia from 2005 to 2007 to test the relationship between ISO 14000 certification and ROE, and emphasizes the necessity of ISO 14000 certification. Marcineková and Sujová (2015) tests the dependence of ROE on enterprise capability maturity and ISO standards. Therefore, this study was repeated using ROE as a dependent variable to substitute ROA. ROE is expressed as the percentage rate of after-tax profit divided by net assets to measure a company's efficiency in using its own capital. After data merging and tallying, 10,626 observations were obtained. New samples were matched using the CEM method to obtain a final 7,617 observations.

The results of the robustness test are shown in Table 5. Model 1 shows that the coefficient of ISO 27001 is $0.013, \mathrm{p}<0.01$; therefore, Hypothesis One is still valid after the dependent variable 
is replaced. The Experience coefficient in Model 2 is $0.001, \mathrm{p}<0.10$, which provides additional support for Hypothesis Two. The Unpublic coefficient in Model 3 is $-0.023, \mathrm{p}<0.01$, which means that unpublished certification is harmful to financial performance, and Hypothesis Three is further verified. Overall, although the significance of some variables and the goodness of fit of the model have declined, the relationship between the variables remains unchanged and the above conclusions are verified.

\section{CONCLUSION}

This study proposes that obtaining ISO 27001 certification helps companies to improve financial performance. The study also analyzes the impact of accumulated ISO 27001 system experience on the financial performance of Chinese listed companies, the possible reasons and effects of non-publicized certification, and confirms the importance of instant disclosure of ISO 27001 certification. This empirical study presents three main findings that provide a financial basis for introducing information security certification systems into enterprises.

First, there is a positive correlation between obtaining information security management system certification and enterprise performance (Hypothesis One). This finding is similar to previous research on other international standard certifications that provide evidence of certification implementation contributing to the improvement of financial performance (Lafuente \& Abad, 2018; Thakore, et al., 2013). Through ISO 27001 certification, firms can minimize information security risks, improve corporate image, and improve corporate performance (Pecina, et al., 2011). Some previous studies have expressed doubts regarding the value of certification due to the decrease in financial performance in the early stages of implementing certification (Goedhuys \& Sleuwaegen, 2013), stating that the initial investment is difficult to offset in the short term with the benefits brought by certification. The results of this study show that the investment in ISO 27001 system ultimately leads to an increase in profitability. Since the independent variable we use (ISO 27001) belongs to the current period rather than the lag period, the results also show that the positive effect of implementing certification on financial performance can be reflected within the same year.

This research provides the basis for strategic decision-making regarding ISO 27001 certification. Some scholars suggest that many enterprises only choose one certification to implement because of the high cost and complexity in practice (Qi, et al., 2013). Anticipating that newer certifications may be detrimental to financial performance, managers tend to choose one certification that is widely recognized or closely monitored by stakeholders (Pheng \& Kwang, 2005). Although ISO 27001 standard is applicable to many types of organizations (ISO, 2013), it is a relatively recent certification and its acceptance and acquisition proportion is low in relation to other types of certification. However, efficiencies can be found in integrating ISO 27001 into a system composed of multiple certifications (Muzaimi, et al., 2017), senior managers do not need to worry that the investment of ISO 27001 certification may be higher than the financial income from its benefits.

Second, the results show that with the accumulation of experience in implementing ISO 27001 system, enterprise performance increases (Hypothesis Two). Some scholars express doubt whether certifications can bring sustained performance growth. For instance, Heras-Saizarbitoria, et al. (2011) state that long-term performance improvement is due to the selection-effects of ISO 14001 certification (which means that more profitable companies are more likely to pursue environmental certification) rather than the improvement of management practice brought about by certification. Zeng, et al. (2007) believe that over-reliance on certified signal functions will lead to the unsustainable expectations for performance improvement. Casadesús and Karapetrovic (2005) suggest that the benefit of ISO 9000 certification on financial performance will gradually decrease over time. Other scholars state that while accumulated certification experience can improve the performance of enterprises, the level of improvement is affected by factors such as certification's target, the industry, the type of performance, and the level of certification implementation (Lafuente \& Abad, 2018). Different from 
Table 5. Robustness Check

\begin{tabular}{|c|c|c|c|c|c|c|}
\hline \multirow{2}{*}{ VARIABLES } & \multicolumn{2}{|l|}{ Model 1} & \multicolumn{2}{|l|}{ Model 2} & \multicolumn{2}{|l|}{ Model 3} \\
\hline & Coefficient & VIF & Coefficient & VIF & Coefficient & VIF \\
\hline \multirow[t]{2}{*}{ ISO 27001} & $0.012 * * *$ & 1.048 & & & & \\
\hline & $(0.003)$ & & & & & \\
\hline \multirow[t]{2}{*}{ Experience } & & & $0.001 *$ & 1.044 & & \\
\hline & & & $(0.001)$ & & & \\
\hline \multirow[t]{2}{*}{ Unpublic } & & & & & $-0.023^{* * *}$ & 1.057 \\
\hline & & & & & $(0.003)$ & \\
\hline \multirow[t]{2}{*}{ Size } & $0.002 * * *$ & 1.600 & $0.002 * * *$ & 1.601 & $0.003^{* * *}$ & 1.587 \\
\hline & $(0.001)$ & & $(0.001)$ & & $(0.001)$ & \\
\hline \multirow[t]{2}{*}{ Asset Liability Ratio } & $0.066^{* * *}$ & 2.336 & $0.066^{* * *}$ & 2.337 & $0.066^{* * *}$ & 2.336 \\
\hline & $(0.005)$ & & $(0.005)$ & & $(0.005)$ & \\
\hline \multirow[t]{2}{*}{ Current Ratio } & 0.000 & 1.922 & 0.000 & 1.923 & 0.000 & 1.922 \\
\hline & $(0.000)$ & & $(0.000)$ & & $(0.000)$ & \\
\hline \multirow[t]{2}{*}{ Operating Cost Rate } & $-0.118 * * *$ & 1.758 & $-0.118 * * *$ & 1.757 & $-0.119 * * *$ & 1.760 \\
\hline & $(0.004)$ & & $(0.004)$ & & $(0.004)$ & \\
\hline \multirow[t]{2}{*}{ Retained Earnings Rate } & $0.021 * * *$ & 1.074 & $0.020 * * *$ & 1.074 & $0.020 * * *$ & 1.074 \\
\hline & $(0.002)$ & & $(0.002)$ & & $(0.002)$ & \\
\hline \multirow[t]{2}{*}{ Growth Rate } & $-0.002 * *$ & 1.192 & $-0.002 * *$ & 1.191 & $-0.002 * *$ & 1.190 \\
\hline & $(0.001)$ & & $(0.001)$ & & $(0.001)$ & \\
\hline \multirow[t]{2}{*}{ SOE } & $-0.013^{* * *} *$ & 1.265 & $-0.014 * * *$ & 1.263 & $-0.013^{* * *} *$ & 1.271 \\
\hline & $(0.002)$ & & $(0.002)$ & & $(0.002)$ & \\
\hline Year Control & Yes & & Yes & & Yes & \\
\hline Industry Control & Yes & & Yes & & Yes & \\
\hline \multirow[t]{2}{*}{ Constant } & $0.146^{* * * *}$ & & $0.143 * * *$ & & $0.137 * * *$ & \\
\hline & $(0.027)$ & & $(0.027)$ & & $(0.027)$ & \\
\hline Observations & 7617 & & 7617 & & 7617 & \\
\hline R-squared & 0.152 & & 0.149 & & 0.154 & \\
\hline F test & 28.80 & & 28.31 & & 29.36 & \\
\hline
\end{tabular}

${ }^{* * *} p<0.01,{ }^{* *} p<0.05,{ }^{*} p<0.1$

these studies, this study shows that ISO 27001 certification has a continuous improvement effect on corporate financial performance, which provides an empirical basis for the implementation of ISO 27001 system.

Third, this study for the first time finds that concealing certification from the public is harmful to financial performance (Hypothesis Three). Previous studies have explored the reasons why senior managers choose not to publicize certifications, such as concerns about the cost of certification, consideration of corporate reputation, and avoidance of pressure from stakeholders (Carlos \& Lewis, 2018). Similarly, these factors have a negative impact on the relationship between ISO 27001 certification and corporate financial performance. İlkay and Aslan (2012) also note that diversity 
in managers' motivation to obtain certification leads to differences in the effect of certification on corporate performance. However, there are few empirical studies on the relationship between concealed certifications and financial performance. This research shows that the intentional concealment of certification information will weaken the role of certification in improving corporate financial performance. Senior managers should seek to reach a strategic consensus with stakeholders and disclose certification information in a timely manner to ensure the effective implementation of the information security system.

Our study also contributes to practice. First, this study encourages executives to implement ISO 27001 systems. Our research demonstrates that the implementation of ISO 27001 systems improves the financial performance of enterprises, and should be used as a tool to improve management practices. Second, our results provide an empirical basis for executives to implement ISO 27001 systems consistently. This study shows that financial performance becomes better as ISO 27001 implementing experience accumulated. This will assist managers to gain confidence in using information security certification. Finally, our study has important significance for executives to publish ISO 27001 certification instantly. In the study, we find there is different financial performance from ISO 27001 certification for companies with different information disclosure strategies. Executives who concealed certification should pay more attention to examine and solve their contradictions with stakeholders to avoid unnecessary losses caused by the non-disclosure of certification.

\section{Limitations and Future Research}

Although this research provides insight into the relationship between information security certification and corporate financial performance, there are some limitations. First, the sample is based on Chinese listed companies. Different countries and regions have different attitudes towards ISO certifications due to factors such as the severity of local conditions and cultural differences (Fryxell, et al., 2004). It is, therefore, necessary to be cautious in applying the results of certification research to other countries or regions.

Second, the research considers the improvement of financial performance after obtaining ISO 27001 certification, but not to other aspects of performance. Other studies on ISO certification examine the impact of certification on different aspects of corporate performance, such as organizational performance and operational performance (Orzes, et al., 2017). The implementation of ISO 27001 system may also affect other performance parameters.

Future research should further investigate the impact of ISO 27001 system implementation on other aspects of the enterprise to comprehensively assess the role of ISO 27001 system in overall company performance. Scholars should also focus on the synergistic effect of information security certification with other certifications, such as quality, environment, and health. Finally, it is necessary to further study the mechanism between information security certification and new technology, to better promote the compatibility between information security certification and new technology, such as the compatibility between information security certification and blockchain technology. 


\section{REFERENCES}

Aba, E. K., Badar, M. A., \& Hayden, M. A. (2015). Impact of ISO 9001 certification on firms financial operating performance. International Journal of Quality \& Reliability Management, 33(1), 78-89. doi:10.1108/ IJQRM-02-2014-0021

Abad, J., Lafuente, E., \& Vilajosana, J. (2013). An assessment of the OHSAS 18001 certification process: Objective drivers and consequences on safety performance and labour productivity. Safety Science, 60, 47-56. doi:10.1016/j.ssci.2013.06.011

Al-Momani, A. M., Mahmoud, M. A., \& Ahmad, M. S. (2018). Factors That Influence the Acceptance of Internet of Things Services by Customers of Telecommunication Companies in Jordan. Journal of Organizational and End User Computing, 30(4), 51-63. doi:10.4018/JOEUC.2018100104

Anderson, R. (2001). Why information security is hard-an economic perspective. Academic Press.

Avdalovic, P., Jovanovic, J. S., Pekovic, S., Vujovic, A., \& Krivokapic, Z. (2018). ISO 9001: 2015 as a Framework for Creation of a Simulation Model for Business Processes. Academic Press.

Beckers, K., Heisel, M., Solhaug, B., \& Stølen, K. (2014). ISMS-CORAS: A structured method for establishing an ISO 27001 compliant information security management system Engineering Secure Future Internet Services and Systems, 315-344.

Bidgoli, H. (2006). Handbook of Information Security, Information Warfare, Social, Legal, and International Issues and Security Foundations (Vol. 2). John Wiley \& Sons.

Bulgurcu, B., Cavusoglu, H., \& Benbasat, I. (2010). Information security policy compliance: An empirical study of rationality-based beliefs and information security awareness. Management Information Systems Quarterly, 34(3), 523-548. doi:10.2307/25750690

Carlos, W. C., \& Lewis, B. W. (2018). Strategic silence: Withholding certification status as a hypocrisy avoidance tactic. Administrative Science Quarterly, 63(1), 130-169. doi:10.1177/0001839217695089

Casadesús, M., \& Karapetrovic, S. (2005). The erosion of ISO 9000 benefits: A temporal study. International Journal of Quality \& Reliability Management, 22(2), 120-136. doi:10.1108/02656710510577198

Chang, K. C., \& Seow, Y. M. (2019). Protective Measures and Security Policy Non-Compliance Intention. Journal of Organizational and End User Computing, 31(1), 1-21. doi:10.4018/JOEUC.2019010101

Cheng, L. C., Wu, C. C., \& Chen, C. Y. (2019). Behavior Analysis of Customer Churn for a Customer Relationship System: An Empirical Case Study. Journal of Global Information Management, 27(1), 111-127. doi:10.4018/ JGIM.2019010106

Dao, T. K., Tapanainen, T. J., Nguyen, H. T. T., Nguyen, T. H., \& Nguyen, N. D. (2017). Information safety, corporate image, and intention to Use online services: Evidence from travel industry in Vietnam. Academic Press.

Davis, R. E. (2017). Relationship between Corporate Governance and Information Security Governance Effectiveness in United States Corporations. Academic Press.

Edmondson, A. C. (2011). Strategies for learning from failure. Harvard Business Review, 89(4), 48-55. PMID:21510518

Edwards, G. (2011). Federal government information systems security management and governance are pacing factors for innovation. Walden University.

Elving, W. J., Golob, U., Podnar, K., Ellerup-Nielsen, A., \& Thomson, C. (2015). The bad, the ugly and the good: New challenges for CSR communication. Corporate Communications, 20(2), 118-127. doi:10.1108/ CCIJ-02-2015-0006

Ferreira Rebelo, M., Santos, G., \& Silva, R. (2014). A generic model for integration of quality, environment and safety management systems. The TQM Journal, 26(2), 143-159. doi:10.1108/TQM-08-2012-0055

Froger, G., Boisvert, V., Méral, P., Coq, J. F., Caron, A., \& Aznar, O. (2015). Market-Based instruments for ecosystem services between discourse and reality: An economic and narrative analysis. Sustainability, 7(9), 11595-11611. doi:10.3390/su70911595 
Fryxell, G. E., Shan, S. C., \& Lo, C. W. H. (2004). Does the selection of ISO 14001 registrars matter? Registrar reputation and environmental policy statements in China. Journal of Environmental Management, 71(1), 45-57. doi:10.1016/j.jenvman.2004.01.005 PMID:15084359

Gallivan, M. J. (2001). Meaning to change: How diverse stakeholders interpret organizational communication about change initiatives. IEEE Transactions on Professional Communication, 44(4), 243-266. doi:10.1109/47.968107

Godfrey, P. C. (2005). The relationship between corporate philanthropy and shareholder wealth: A risk management perspective. Academy of Management Review, 30(4), 777-798. doi:10.5465/amr.2005.18378878

Goedhuys, M., \& Sleuwaegen, L. (2013). The impact of international standards certification on the performance of firms in less developed countries. World Development, 47, 87-101. doi:10.1016/j.worlddev.2013.02.014

Gordon, L. A., Loeb, M. P., \& Sohail, T. (2003). A Framework for Using Insurance for Cyber-Risk Management. Communications of the ACM, 46(3), 81-85. doi:10.1145/636772.636774

Hall, J. H. (2011). Examining Impacts of Organizational Capabilities in Information Security: A Structural Equation Modeling Analysis. Dissertations \& Theses - Gradworks, 205.

Heras-Saizarbitoria, I., Molina-Azorín, J. F., \& Dick, G. P. M. (2011). ISO 14001 certification and financial performance: Selection-effect versus treatment-effect. Journal of Cleaner Production, 19(1), 1-12. doi:10.1016/j. jclepro.2010.09.002

Hung, W. H., Chang, I. C., Chen, Y., \& Ho, Y. L. (2019). Aligning 4C Strategy with Social Network Applications for CRM Performance. Journal of Global Information Management, 27(1), 93-110. doi:10.4018/ JGIM.2019010105

Iacus, S. M., King, G., \& Porro, G. (2009). CEM: software for coarsened exact matching. Academic Press.

Iacus, S. M., King, G., \& Porro, G. (2011). Multivariate matching methods that are monotonic imbalance bounding. Journal of the American Statistical Association, 106(493), 345-361. doi:10.1198/jasa.2011.tm09599

İlkay, M. S., \& Aslan, E. (2012). The effect of the ISO 9001 quality management system on the performance of SMEs. International Journal of Quality \& Reliability Management, 29(7), 753-778. doi:10.1108/02656711211258517

ISO. (2013). Information Technology, Security Techniques, Code of Practice for Information Security Management. International Organization for Standardization ISO.

ISO. (2018). The ISO survey of management system standard certifications - 2018 - explanatory note. ISO.

Lafuente, E., \& Abad, J. (2018). Analysis of the relationship between the adoption of the OHSAS 18001 and business performance in different organizational contexts. Safety Science, 103, 12-22. doi:10.1016/j. ssci.2017.11.002

Lee, S. M., Noh, Y., Choi, D., \& Rha, J. S. (2017). Environmental policy performances for sustainable development: From the perspective of ISO 14001 certification. Corporate Social Responsibility and Environmental Management, 24(2), 108-120. doi:10.1002/csr.1395

Lele, Q., \& Lihua, K. (2016). Technical framework design of safety production information management platform for chemical industrial parks based on cloud computing and the Internet of things. International Journal of Grid and Distributed Computing, 9(6), 299-314. doi:10.14257/ijgdc.2016.9.6.28

Lin, C. P., Tsai, Y. H., Chiu, C. K., \& Liu, C. P. (2015). Forecasting the purchase intention of IT product: Key roles of trust and environmental consciousness for IT firms. Technological Forecasting and Social Change, 99 , 148-155. doi:10.1016/j.techfore.2015.06.034

Lo, C. K. Y., Yeung, A. C. L., \& Cheng, T. C. E. (2011). Meta-standards, financial performance and senior executive compensation in China: An institutional perspective. International Journal of Production Economics, 129(1), 119-126. doi:10.1016/j.ijpe.2010.09.011

Lo, C. K. Y., Yeung, A. C. L., \& Cheng, T. C. E. (2012). The impact of environmental management systems on financial performance in fashion and textiles industries. International Journal of Production Economics, 135(2), 561-567. doi:10.1016/j.ijpe.2011.05.010 
Lyon, T. P., \& Montgomery, A. W. (2013). Tweetjacked: The Impact of Social Media on Corporate Greenwash. Journal of Business Ethics, 118(4), 747-757. doi:10.1007/s10551-013-1958-x

Marcineková, K., \& Sujová, A. (2015). The Influence of the Process Control Level on the Enterprises' ROE. Procedia Economics and Finance, 34, 290-295. doi:10.1016/S2212-5671(15)01632-9

Martí-Calatayud \& Pérez-Herranz. (2011). The twelfth five-year plan for national economic and social development of the People's Republic China. Central Compilation \& Translation Press.

Moghe, P., Gehani, N., \& Smith, P. T. (2014). Enterprise information asset protection through insider attack specification, monitoring and mitigation. Google Patents.

Montiel, I., Husted, B. W., \& Christmann, P. (2012). Using private management standard certification to reduce information asymmetries in corrupt environments. Strategic Management Journal, 33(9), 1103-1113. doi:10.1002/smj.1957

Muzaimi, H., Chew, B. C., \& Hamid, S. R. (2017). Integrated management system: The integration of ISO 9001, ISO 14001, OHSAS 18001 and ISO 31000. Academic Press.

Nga, J. K. H. (2009). The influence of ISO 14000 on firm performance. Social Responsibility Journal, 5(3), 408-422. doi:10.1108/17471110910977311

Nugraha, Y., \& Martin, A. (2017). Investigating Security Capabilities in Service Level Agreements as TrustEnhancing Instruments. Academic Press.

Okoye, S. I. (2017). Strategies to Minimize the Effects of Information Security Threats on Business Performance. Academic Press.

Orzes, G., Jia, F., Sartor, M., \& Nassimbeni, G. (2017). Performance implications of SA8000 certification. International Journal of Operations \& Production Management, 37(11), 1625-1653. doi:10.1108/ IJOPM-12-2015-0730

Pecina, K., Estremera, R., Bilbao, A., \& Bilbao, E. (2011). Physical and Logical Security management organization model based on ISO 31000 and ISO 27001. Academic Press.

Peltier, T. R. (2016). Information Security Policies, Procedures, and Standards: guidelines for effective information security management (Vol. 1). Auerbach Publications. doi:10.1201/9780849390326

Peng, J., Quan, J., \& Peng, L. (2019). IT Application Maturity, Management Institutional Capability and Process Management Capability. Journal of Organizational and End User Computing, 31(1), 61-85. doi:10.4018/ JOEUC.2019010104

Pheng, L. S., \& Kwang, G. K. (2005). ISO 9001, ISO 14001 and OHSAS 18001 management systems: Integration, costs and benefits for construction companies. Architectural Science Review, 48(2), 145-151. doi:10.3763/ asre.2005.4818

Priede, J. (2012). Implementation of quality management system ISO 9001 in the world and its strategic necessity. Procedia: Social and Behavioral Sciences, 58, 1466-1475. doi:10.1016/j.sbspro.2012.09.1133

Qi, G., Zeng, S., Yin, H., \& Lin, H. (2013). ISO and OHSAS certifications: How stakeholders affect corporate decisions on sustainability. Management Decision, 51(10), 1983-2005. doi:10.1108/MD-11-2011-0431

Sampaio, P., Saraiva, P., \& Guimarães Rodrigues, A. (2011). The economic impact of quality management systems in Portuguese certified companies: Empirical evidence. International Journal of Quality \& Reliability Management, 28(9), 929-950. doi:10.1108/02656711111172522

Santos, G., Rebelo, M., Lopes, N., Alves, M. R., \& Silva, R. (2016). Implementing and certifying ISO 14001 in Portugal: Motives, difficulties and benefits after ISO 9001 certification. Total Quality Management \& Business Excellence, 27(11-12), 1211-1223. doi:10.1080/14783363.2015.1065176

Sharma, D. S. (2005). The association between ISO 9000 certification and financial performance. The International Journal of Accounting, 40(2), 151-172. doi:10.1016/j.intacc.2005.01.011 
Siougle, E., Economidou, C., Drivas, K., \& Dimelis, S. (2018). Does ISO 9000 certification matter for firm performance? A group matched analysis of Greek listed firms. International Journal of Production Economics, $3,1-41$.

Siponen, M. T. (2000). A conceptual foundation for organizational information security awareness. Information Management \& Computer Security, 8(1), 31-41. doi:10.1108/09685220010371394

Song, D. (2019). Effects of the ISO 14001 Voluntary Environmental Program on Economic and Environmental Performance. Academic Press.

Spears, J. L. (2007). Institutionalizing information security risk management: A multi-method empirical study on the effects of regulation. Academic Press.

Terlaak, A., \& King, A. A. (2006). The effect of certification with the ISO 9000 Quality Management Standard: A signaling approach. Journal of Economic Behavior \& Organization, 60(4), 579-602. doi:10.1016/j. jebo.2004.09.012

Thakore, R. B., Lowe, C. N., \& Nicholls, T. (2013). Financial Impact of Certified ISO 14001 Environment Management Systems in the UK and Ireland. ICSDEC 2012: Developing the Frontier of Sustainable Design, Engineering, and Construction, 894-902.

Tsai, S. B., Huang, C. Y., Wang, C. K., Chen, Q., Pan, J., Wang, G., \& Deng, Y. et al. (2016). Using a Mixed Model to Evaluate Job Satisfaction in High-Tech Industries. PLoS One, 11(5), e0154071. doi:10.1371/journal. pone.0154071 PMID:27139697

Ullah, B., Wei, Z., \& Xie, F. (2014). ISO certification, financial constraints, and firm performance in Latin American and Caribbean countries. Global Finance Journal, 25(3), 203-228. doi:10.1016/j.gfj.2014.10.003

Wu, C. H., \& Tsai, S. B. (2018). Using DEMATEL-Based ANP model to measure the successful factors of E-commerce. Intelligent Systems: Concepts, Methodologies, Tools, and Applications, 1122-1138.

Yaokumah, W., Walker, D. O., \& Kumah, P. (2019). SETA and Security Behavior: Mediating Role of Employee Relations, Monitoring, and Accountability. Journal of Global Information Management, 27(2), $102-121$. doi:10.4018/JGIM.2019040106

Zeng, S. X., Tian, P., \& Tam, C. M. (2007). Overcoming barriers to sustainable implementation of the ISO 9001 system. Managerial Auditing Journal, 22(3), 244-254. doi:10.1108/02686900710733125

Wenqing Wu is a full professor in College of Management and Economics, Tianjin University, China. His research interests focus on intellectual capital, innovation management, knowledge management, e-commerce- ICT and SEMs.

Kun Shi is a candidate doctor at the College of Management and Economics, Tianjin University. His research interests focus on innovation management, knowledge management, e-commerce- ICT and SEMs.

Chia-Huei Wu is the corresponding author of this paper. She is the associate professor of Institute of Service Industries and Management, Minghsin University of Science Technology, Taiwan. Her research interests focus on intellectual capital, innovation management, knowledge management, e-commerce, ICT, and SEMs.

Jiayue Liu is the corresponding author of this paper. She is the associate professor of School of Marine Science and Technology, Tianjin University. Her research interests focus on marine information technology, transformation of marine achievements. 